\title{
Life cycle assessment of a typical European single-family residence and its flood related repairs
}

Hennequin, Thomas; Dong, Yan; Arnbjerg-Nielsen, Karsten; Sørup, Hjalte Jomo Danielsen

Published in:

Journal of Cleaner Production

Link to article, DOI:

10.1016/j.jclepro.2019.04.125

Publication date:

2019

Document Version

Peer reviewed version

Link back to DTU Orbit

Citation (APA):

Hennequin, T., Dong, Y., Arnbjerg-Nielsen, K., \& Sørup, H. J. D. (2019). Life cycle assessment of a typical European single-family residence and its flood related repairs. Journal of Cleaner Production, 228, 1334-1344. https://doi.org/10.1016/j.jclepro.2019.04.125

\section{General rights}

Copyright and moral rights for the publications made accessible in the public portal are retained by the authors and/or other copyright owners and it is a condition of accessing publications that users recognise and abide by the legal requirements associated with these rights.

- Users may download and print one copy of any publication from the public portal for the purpose of private study or research.

- You may not further distribute the material or use it for any profit-making activity or commercial gain

- You may freely distribute the URL identifying the publication in the public portal 


\section{Life cycle assessment of a typical European single- 2 family residence and its flood related repairs}

3 Thomas Hennequin ${ }^{a}$ (corresponding author), Yan Dong ${ }^{b, c}$, Karsten Arnbjerg-Nielsen ${ }^{a, b}$, Hjalte Jomo Danielsen Sørup ${ }^{a, b}$

5 a: Urban Water Systems, Department of Environmental Engineering, Technical University of Denmark, Bygningstorvet, Building 115, 2800 Kgs. Lyngby, Denmark (thhen@env.dtu.dk, karn@env.dtu.dk, hjds@env.dtu.dk)

b: Global Decision Support Initiative, Technical University of Denmark c: Quantitative Sustainability Assessment, Department of Management Engineering, Technical University of Denmark (yado@dtu.dk)

Abstract: Floods are a constant threat to ecosystems, humans, infrastructure and assets. The combination of increased urbanization and rising sea levels makes it a concern of increasing societal importance. This study offers a new perspective on environmental impact assessment of flood related repairs related to a single-family residence using life cycle assessment. A typical European house built in the 2010's is modelled in the life cycle assessment framework with focus on items damaged by a flood. Flood damage is assessed on the detail level of the house's different components using flood depth as the indicator of damage level. A life cycle inventory is built individually for each considered item group affected by flooding. The influence of flood depths and house ages are studied. The results show that the main impacts of flood related repairs come from the replacement of the wooden flooring, the water heater and furniture. Overall, flood related repairs add between 3.5 and $17.8 \%$ of environmental impacts to the life cycle of the house depending on house age and flood depth; deeper water and bad timing in relation to maintenance cycles causing more impacts. Moreover, a very high positive correlation between environmental and economic impact is found in most impact categories. 


\section{Introduction}

The residential sector is one of the anthropologic activities with the highest impact on the environment, amounting to $40 \%$ of global energy use and $38 \%$ of global greenhouse gases emissions (UNEP, 2012). To assess this environmental burden, Life Cycle Assessment (LCA) is often used. Numerous LCAs have assessed the impact of residences or of the built environment (Goldstein et al., 2018; Khasreen et al., 2009; Lasvaux et al., 2017; Roux et al., 2016; Vilches et al., 2016). However, amongst the various life cycle phases of a house, the regular maintenance and the repairs needed after a natural disaster are seldom within the scope. Few examples choose to include earthquake, hurricane or flood related repairs (Matthews et al., 2016; Sarkisian, 2014; Sudret et al., 2014).

Accounting for half of the occurrences and mortality of natural disasters and resulting in the largest insured losses of all natural catastrophes, flooding is a constant threat to ecosystems, humans, and infrastructure (Guha-Sapir, 2016; Munich Re, 2017). The interplay with other stakeholders and social implications makes flood risk management particularly difficult (Aerts et al., 2018). Moreover, this risk increases dramatically over time because of sea level rise (Arnbjerg-Nielsen et al., 2015; Hirabayashi et al., 2013) and urbanization (UN, 2014). It is a societal concern that cannot and should not be ignored, especially in the context of climate adaptation. Natural disasters and their consequences have been studied in literature, mainly within the field of risk assessment, where risk is defined as a combination of probability of occurrence and potential economic damage calculated from depth-damage curves (Aerts et al., 2018; Morita, 2008). While this is efficient in terms of economic optimization, it may be less optimal in terms of resource consumption, which may in turn lead to unnecessarily high environmental consequences. Hence more integrated assessments, such as LCA, may offer a more comprehensive and consistent view of flood damage versus flood protection.

The LCA framework has indeed recently been used to assess flood prevention, namely, infrastructure construction such as concrete walls and ripraps, while integrating avoided damage (Petit-Boix et al., 2016). It was also used to assess flood damage in the context of stormwater best management practices (Petit-Boix et al., 2017). Finally, the choice of materials and configuration of a flood resilient single family residence were optimized by combining LCA and a Monte Carlo analysis which included sea level rise (Matthews et al., 2016).

While researchers are increasingly aware of a flood's environmental consequences, it is argued that further improvement of its assessments is needed. Even when LCA is used, the impact categories are constrained to carbon footprint, water depletion and embodied energy (Matthews et al., 2016). By conducting 
a full LCA, this study intends to avoid burden shifting by producing a thorough assessment. It also attempts to bring together the fields of resource optimization and risk assessments, notably by using the same type of depth-damage relationship. Moreover, the environmental impact of flood related repairs is compared to a baseline house with no flooding using a comparative LCA. This is believed to further extend the reach of this study by appealing to decision makers with communicative and versatile results.

The objective of this study is to develop and exemplify a methodology enabling the inclusion of flood related repairs in the LCA of a house. By analysing the results, two major questions will be answered: the amount of additional impact a house has on the environment when it is flooded once, and whether there is a correlation between economic and environmental flood damage. Moreover, the main contributor of flood related repairs' environmental impact will be identified and the importance of the house age when the flood occurs is scrutinized.

\section{Method}

The LCA methodology is extensively standardized through ISO 14040 and 14044 (ISO, 2006a, 2006b). It is used worldwide by decision makers in a variety of fields. The method used in this study to conduct a comparative LCA is presented in this section and consists of four main steps.

First, the aims and scope of the study are defined through the functional unit and system boundaries. All the phases of the house's lifecycle that would happen irrespective of the flood occurrence are excluded. As a result, the focus is drawn to flood related repairs and an inventory for these repairs is constructed in two stages. The first stage is the flood damage assessment based on the work of the United States Army Corps of Engineers (USACE), which allows to identify the items damaged by a flood, using maximum water depth as an indicator. Then, based on the items identified, a house is modelled in the LCA framework with characteristics chosen to represent a typical European single-family residence. Life Cycle Inventories (LCls) are built for each of the items constituting the house, mainly using Environmental Product Declarations (EPDs). The next step is to determine the amount of each item needed for each flooding scenario, including a baseline with no flood. Finally, a sensitivity analysis is conducted to assess the robustness of the model.

\subsection{Functional unit and system boundaries}

The functional unit is building and maintaining a typical European single-family residence built in the 2010's over its 120 years expected lifetime. The resource consumption in relation to human use of the house 
are omitted. This way we focus on the resource consumption related to the physical house itself. The aim is to conduct a comparative LCA study that includes numerous scenarios through which two situations are compared, one with and one without flooding. The former consists in one scenario, the baseline, while the latter is a range of flood scenarios exploring two dimensions of the issue, namely, flood depth and the house age. The baseline scenario consists in a basic LCA of a house and is used mainly as an element of comparison whereas the flooding scenarios focus largely on flood related repairs.

The system boundaries chosen for both cases are listed in Table 1. The exclusions of the use phase, the demolition and the recycling lie in the comparative nature of the LCA as they would have to occur irrespective of whether a flood occurs or not. The construction phase is modelled as the addition of all the items making up the house, omitting construction site activities, such as excavation for the foundations or the use of scaffolding, as their impact is negligible (Lasvaux et al., 2017). It is hypothesized that the maintenance cycles will be affected by flooding, making the inclusion of the maintenance phase a necessity. Both the maintenance phase and the flood related repairs consists in complete or partial replacements of items. In the former, items that reached the end of their lifetime are replaced and, in the latter, items damaged by the flood are replaced (see section 2.2.1). Finally, given that the lifetime of the house was modelled on a decadal scale, the house's content such as cloths or consumers electronics were excluded as their short lifetimes leads their replacement to be independent of flooding.

It is argued that these scenarios and system boundaries allow to focus on flood related repairs while contextualizing them in the life cycle of the house. Given the intent to target flood related repairs, the next step is to map all processes and items involved in that phase, for different flood scenarios, and organize them in an inventory.

Table 1 - LCA system boundaries for the two cases, where $X$ stands for excluded and $\checkmark$ for included.

\begin{tabular}{|l|c|c|}
\hline Life cycle phase & Baseline & Flood \\
\hline Construction & $\checkmark$ & $\checkmark$ \\
\hline Maintenance (replacement, reparations) & $\checkmark$ & $\checkmark$ \\
\hline Use (heating, electricity, water, etc.) & $\mathrm{X}$ & $\mathrm{X}$ \\
\hline Flood related repairs & $\mathrm{X}$ & $\checkmark$ \\
\hline Demolition & $\mathrm{X}$ & $\mathrm{X}$ \\
\hline Recycling of construction materials & $\mathrm{X}$ & $\mathrm{X}$ \\
\hline
\end{tabular}




\subsubsection{Flood damage assessment}

Before modelling the house in the LCA framework, flood damage is assessed in order to map items in the house that are expected to be damaged and make them a priority. To do so, the flood maximum depth, denoted $F D$, was chosen as the indicator of damage. Traditionally, in the field of risk assessment, this would be done using stage-damage curves built with historical data. However, this type of curve yields values on the scale of different land uses, meaning a single damage value for roads or for commercial buildings. A single damage value for the whole residential sector is far too general for the calculations of items flows required here (cf. section 2.3). Indeed, it would mean that the house considered would be uniformly damaged, with the same proportion of repairs needed for items as different as electrical plugs and ceiling insulation. Instead, damage on single items in the house was linked to flood depth using the data from an expert opinion based report commandeered by the USACE (USACE, 2006). This economic assessment was adjusted to yield damage functions, $\operatorname{Di}(F D)$, for each item $i$ considered. The adjustment step consisted in converting economic values into relative values, using whichever was highest between the price of replacement or reparation reported by the USACE as the full damage upper limit. The output for a one-story on slab single-family residence flooded during one day with mixed fresh and salt water is reported in Table 2.

Using this data, one can map flood damage precisely: for a given flood depth, a relative damage value is attributed to each item. For example, for a flood depth of $20 \mathrm{~cm}$, almost a third of the wall insulation is damaged and replaced. This example shows that realistic repairs are considered in the USACE's report, in that case by taking into account the absorption property of the insulation as well as the fact that the gypsum plasterboard needs to be replaced in similar proportions.

It should be noted that basement flooding is considered in the USACE's report, which is why a flood with Om of water is considered damaging. Moreover, flood depths up to $4.6 \mathrm{~m}$ can be found in the USACE report. However, values higher than $2.1 \mathrm{~m}$ are not used in this study as it could result in structural lifting (MiddelmannFernandes, 2010). Instead, the water levels of Table 2 between 0 and $2.1 \mathrm{~m}$ will all be considered, apart from the $0.6 \mathrm{~m}$ level, resulting in nine flooding scenarios. These nine water depths will be assessed for all house ages, in increments of 10 years. This allows the investigation of the first dimension of the flood scenario while describing the associated uncertainty. 


\begin{tabular}{|l|c|c|c|c|c|c|c|c|c|c|}
\cline { 2 - 14 } \multicolumn{1}{c|}{} & \multicolumn{10}{c|}{ Flood level (m) relative to ground floor } \\
\hline Item's category & 0 & 0.2 & 0.3 & 0.5 & 0.6 & 0.9 & 1.2 & 1.5 & 1.8 & 2.1 \\
\hline Heat and cool units/ducts & 28.7 & 38.7 & 53 & 53 & 53 & 55.5 & 66.9 & 66.9 & 66.9 & 66.9 \\
\hline Bottom cabinets & 11.4 & 68.2 & $\mathbf{1 0 0}$ & $\mathbf{1 0 0}$ & $\mathbf{1 0 0}$ & $\mathbf{1 0 0}$ & $\mathbf{1 0 0}$ & $\mathbf{1 0 0}$ & $\mathbf{1 0 0}$ & $\mathbf{1 0 0}$ \\
\hline Plumbing fixtures & 5.6 & 12.7 & 15.3 & 18.8 & 21.6 & 23.4 & 36.7 & 36.7 & 36.7 & 36.7 \\
\hline Flooring/carpet/tile & 34.2 & $\mathbf{1 0 0}$ & $\mathbf{1 0 0}$ & $\mathbf{1 0 0}$ & $\mathbf{1 0 0}$ & $\mathbf{1 0 0}$ & $\mathbf{1 0 0}$ & $\mathbf{1 0 0}$ & $\mathbf{1 0 0}$ & $\mathbf{1 0 0}$ \\
\hline Paint/wallpaper (interior) & 13.9 & 63.8 & 91.7 & 91.7 & 91.7 & 91.7 & $\mathbf{1 0 0}$ & $\mathbf{1 0 0}$ & $\mathbf{1 0 0}$ & $\mathbf{1 0 0}$ \\
\hline Doors/trim & 13.6 & 55.3 & 67.6 & 74.5 & 87.7 & 87.7 & $\mathbf{1 0 0}$ & $\mathbf{1 0 0}$ & $\mathbf{1 0 0}$ & $\mathbf{1 0 0}$ \\
\hline Sheetrock/(walls) & 6.7 & 33.2 & 44.3 & 44.3 & 53.2 & 53.2 & 80.2 & 93.9 & $\mathbf{1 0 0}$ & $\mathbf{1 0 0}$ \\
\hline Wall insulation & 6.5 & 32.3 & 42.4 & 42.4 & 52.2 & 61.3 & 87.1 & $\mathbf{1 0 0}$ & $\mathbf{1 0 0}$ & $\mathbf{1 0 0}$ \\
\hline Baseboard & 14.6 & $\mathbf{1 0 0}$ & $\mathbf{1 0 0}$ & $\mathbf{1 0 0}$ & $\mathbf{1 0 0}$ & $\mathbf{1 0 0}$ & $\mathbf{1 0 0}$ & $\mathbf{1 0 0}$ & $\mathbf{1 0 0}$ & $\mathbf{1 0 0}$ \\
\hline Built-in appliances & 13.1 & 33.9 & 67.8 & 78.7 & 86 & $\mathbf{1 0 0}$ & $\mathbf{1 0 0}$ & $\mathbf{1 0 0}$ & $\mathbf{1 0 0}$ & $\mathbf{1 0 0}$ \\
\hline Electrical and lighting/panel & 1.1 & 3.7 & 3.7 & 15.3 & 30.5 & 31.6 & 50.8 & 65.6 & 75 & 81.9 \\
\hline Counter tops & 13 & 26 & 26 & 26 & 26 & 61.3 & $\mathbf{1 0 0}$ & $\mathbf{1 0 0}$ & $\mathbf{1 0 0}$ & $\mathbf{1 0 0}$ \\
\hline Wall cabinets & 21.8 & 33.4 & 33.4 & 33.4 & 33.4 & 33.4 & 56.7 & $\mathbf{1 0 0}$ & $\mathbf{1 0 0}$ & $\mathbf{1 0 0}$ \\
\hline Windows/trim & 0 & 0 & 0 & 3.4 & 7.6 & 23.9 & 49.3 & 70.1 & 70.1 & 70.1 \\
\hline Ceiling insulation \& ductwork & 0 & 0 & 0 & 0 & 0 & 0 & 0 & 0 & 0 & 0 \\
\hline Roof & 0 & 0 & 0 & 0 & 0 & 0 & 0 & 0 & 0 & 0 \\
\hline Exterior wall/siding & 0 & 3 & 3 & 3 & 8 & 8 & 12.4 & 15.4 & 19 & 19 \\
\hline Slab/foundation & 0 & 0 & 0 & 0 & 0 & 0 & 0 & 0 & 0 & 0 \\
\hline Structural frame & 0.7 & 2.2 & 3.4 & 3.4 & 3.4 & 3.4 & 3.4 & 3.4 & 3.4 & 3.4 \\
\hline Facia/soffit & 0 & 0 & 0 & 0 & 0 & 0 & 0 & 0 & 0 & 0 \\
\hline
\end{tabular}

\subsubsection{House modelled}

The single-family residence was modelled using two main sources: 1) the mapping presented in Table 2 , in order to focus on elements damaged by the flood, and 2) literature references dealing with LCA of houses (Peuportier, 2001; Rasmussen and Birgisdottir, 2015) as well as flooding (Matthews et al., 2016). While diverse types of house designs exist, it was chosen to model a typical European single-family residence built in the 2010s. By modelling a recent, average house, it is argued that representative results are obtained. The resulting design is a $130 \mathrm{~m}^{2}$ house built on a concrete slab, with a brick structural frame, a $20 \mathrm{~cm}$ thick mineral insulation and a 120 years lifetime. Figure 1 illustrates the house modelled with a floorplan, which was also used to dimension several items constituting the house. This figure includes some additional figurative elements such as beds and chairs (cf. Table 3 for list of items included in the flood damage assessment). 


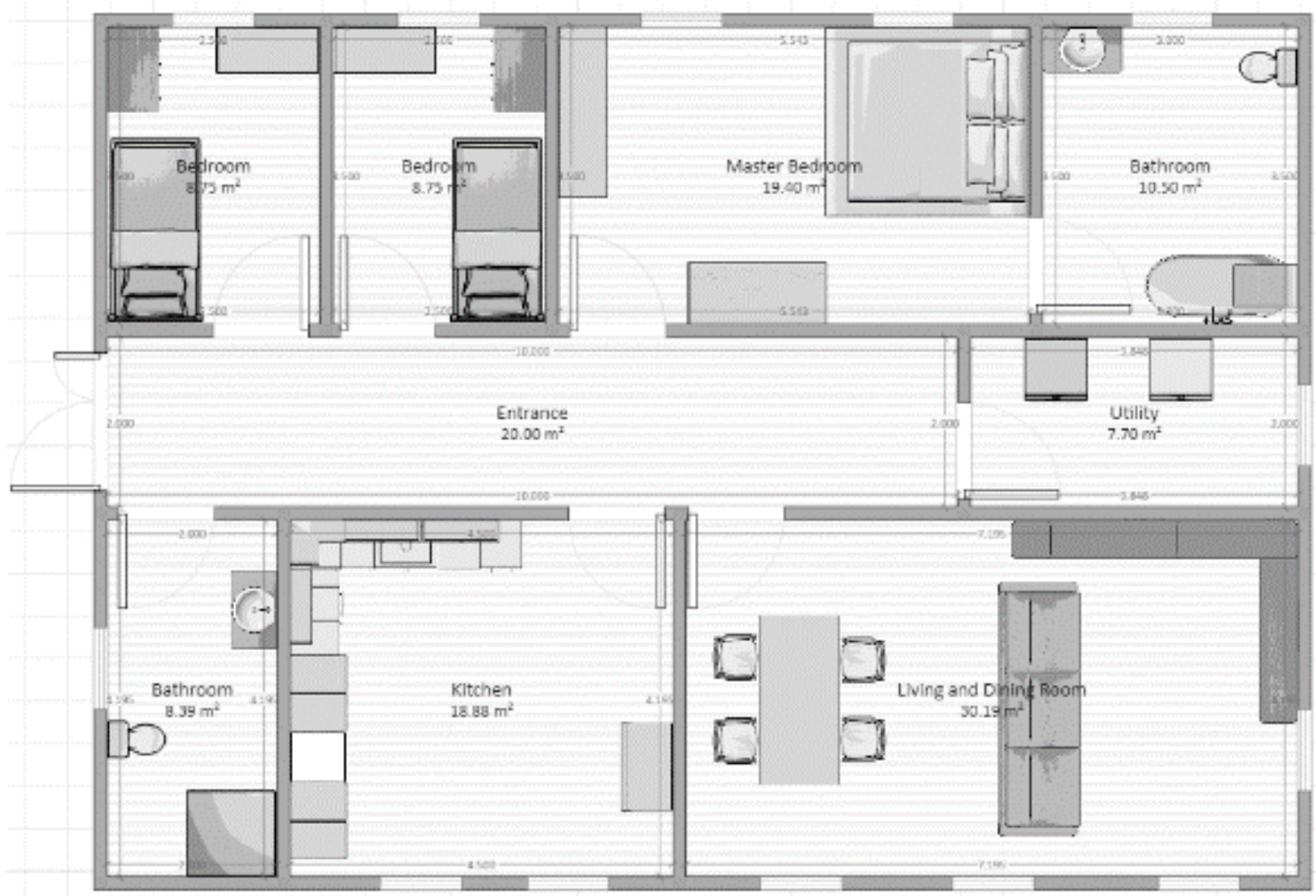

Figure 1 - Floorplan of the single-family residence modelled, with some additional figurative elements such as beds and chairs (cf. Table 3 for list of items included in the flood damage assessment).

Concretely, the house was modelled in the LCA framework as 32 separate items listed in Table 3 . Most of the items selected are affixed to the house except for the wardrobes and living room furniture. An LCA and subsequent Life Cycle Inventory (LCI) were built for each of the 32 items constituting the house. To do so, Environmental Product Declarations (EPDs) of the specific products chosen were used, as it is the most representative data available.

An EPD is a collection of technical data for a given product, issued either by the manufacturer or by governmental agencies as an averaged reference. The data is mainly comprised of an LCA, but also reaches further in certain cases, with health or acoustic assessments. The results of the EPDs' LCAs were not used directly as this would have led to a limited number of impact categories and inconsistencies in LCA methodologies. Instead, the EPDs' LCls were extracted, and the LCAs were rebuilt in SimaPro (Pré Consultants BV, 2018). High fidelity was achieved thanks to the level of detail of the EPDs' LCIs, often referencing precisely which items of different databases were used for a given material or process. 
The EPDs were found on a French open database that references products declared either by the manufacturer or by the French Ministries of Housing and of Ecology (FMHE) (INIES, 2017). All the EPDs used 166 in this study follow the traditional LCA regulation ISO 14044, and are further regulated by the French NF EN 16715804 which deals with EPDs as an entity (INIES, 2017). In some cases, EPDs were replaced by literature 168 studies, when the LCls reported there were transparent enough. Finally, when specific data was not available, 169 generic data from the Ecoinvent v3.2 database was used. The specific sources for each of the item modelled 170 can be found in Table 3. Detailed LCls for each item can be found in the [supplementary material]. All of the 171 items were eventually modelled in SimaPro, using the ReCiPe Midpoint (E) V1.13/Europe (Goedkoop et al., 172 2013).

173 


\begin{tabular}{|c|c|c|}
\hline Category & Items modelled & Source \\
\hline \multirow{3}{*}{ Heat and Cool Units/Ducts } & $1 \mathrm{~kW}$ electric radiator & (Thermor, 2015) \\
\hline & Flexible ventilation duct, $12.5 \mathrm{~cm}$ ND & (FMHE, 2014a) \\
\hline & Mechanical ventilation, simple flux, $60 \mathrm{~m} 3 / \mathrm{h}$ & (Groupe Atlantic, 2015) \\
\hline \multirow{3}{*}{$\begin{array}{l}\text { Bottom/wall cabinets and counter } \\
\text { tops }\end{array}$} & Kitchen cabinet & $\begin{array}{l}\text { (González-García et al., } \\
\text { 2011) }\end{array}$ \\
\hline & Living room furniture & $\begin{array}{l}\text { (González-García et al., } \\
\text { 2011) }\end{array}$ \\
\hline & Wardrobe & (Iritani et al., 2015) \\
\hline \multirow{5}{*}{ Plumbing Fixtures } & Ceramic WC & $\begin{array}{l}\text { (Ideal standard France, } \\
\text { 2016) }\end{array}$ \\
\hline & $10 \mathrm{~kW}$ gas Water heater & (FMHE, 2016a) \\
\hline & PVC pipe & (GIRPI, 2015) \\
\hline & Ceramic kitchen sink & (AFISB, 2014) \\
\hline & Ceramic bathroom sink & $\begin{array}{l}\text { (Ideal standard France, } \\
\text { 2015) } \\
\end{array}$ \\
\hline \multirow{2}{*}{ Flooring } & Ceramic tile & Ceramic tile, GLO \\
\hline & Wooden flooring with decorative paper & (FMHE, 2014b) \\
\hline Paint (interior) & White alkyd paint & Alkyd paint, white, RER \\
\hline \multirow{2}{*}{ Doors/Trim } & Wooden entrance door & (Bel'M, 2012) \\
\hline & Wooden inner door & Door, inner, wood (GLO) \\
\hline Sheetrock/(Walls) & Gypsum plasterboard & Gypsum plasterboard (GLO) \\
\hline Wall and ceiling Insulation & Stone wool & Stone wool (GLO) \\
\hline \multirow{2}{*}{ Base Molding } & Wooden baseboard & (FMHE, 2014c) \\
\hline & Ceramic baseboard & (FMHE, 2014d) \\
\hline \multirow{6}{*}{ Electrical and Lighting/Panel } & Domestic cable & (FMHE, 2017) \\
\hline & Domestic socket & (Legrand, 2016) \\
\hline & Domestic switch & (FMHE, 2016b) \\
\hline & $54 \mathrm{~W}$ lighting & (FMHE, 2016c) \\
\hline & $74 \mathrm{~W}$ suspended lighting & (FMHE, 2016d) \\
\hline & Miniature Circuit Breaker & (Schneider Electric, 2014) \\
\hline Windows/Trim & Double glazed PVC framed window & Window, PVC (GLO) \\
\hline Roof & Clay roof tile & Roof tile, clay (GLO) \\
\hline Exterior Wall/Siding & Wooden painted siding & (FCBA, 2015) \\
\hline \multirow{2}{*}{ Slab/Foundation } & Foundation & \begin{tabular}{|l} 
(Rasmussen and \\
Birgisdottir, 2015) \\
\end{tabular} \\
\hline & Slab & $\begin{array}{l}\text { (Rasmussen and } \\
\text { Birgisdottir, 2015) } \\
\end{array}$ \\
\hline Structural Frame & Structural frame & \begin{tabular}{|l} 
(Rasmussen and \\
Birgisdottir, 2015) \\
\end{tabular} \\
\hline
\end{tabular}




\subsection{Items flows}

The Item Flows (IFs) described in this section refer to the number of each of the 32 items needed for different scenarios. For example, the number of radiators needed when first building the house, or when a flood with a given water level occurs on a house with a given age. It is not to be confused with the reference flow of the overarching comparative LCA, which is one house for all scenarios. It is not to be confused either with the reference flows of the 32 LCAs conducted for each item. The reference flows for the items, as well as their LCls, can be found in the [supplementary material].

The IFs for the baseline scenario are the addition of the two phases included, namely, construction and maintenance. The simplified construction phase consists in the addition of the initial quantities, denoted $I Q_{i}$, for each item $i$. The initial quantities were determined using the references of Table 3, as well as the floor plan of Figure 1, which was used as a canvas to dimension several items (e.g. lengths of ventilation ducts and water pipes or area of flooring, etc.). Additional sources and expert opinions were also used for several items which was reported in the [supplementary materials]. To add the maintenance phase, the initial quantities were multiplied by the ratio of the house lifetime, $L_{H}$, and the item's lifetime, $L_{i}$, leading to:

$$
I F_{i, \text { basline }}=I Q_{i} \cdot \frac{L_{H}}{L_{i}}
$$

Equation 1

The outputs of this equation can be found in Table 4 alongside lifetimes, for all items. It should be noted that the technical lifetimes found in the literature references were often unrealistic and were therefore corrected, using a single unified source (ATD, 2016).

However, while being convenient, Equation 1 only yields correct results when the lifetime of the house is a multiple of the lifetime of the item considered, yielding an underestimation otherwise. Fortunately, the 120 years lifetime of the house is a multiple of most of the items' lifetimes, and the few exceptions with a lifetime of 50 years had their IFs corrected, which is noted in Table 4. To find the correct IFs for items with a 50 years lifetime, the life cycle of the house was divided in decades. For each decade, items that saw their lifetime run out were replaced. While not as straightforward as a single equation, this method allows a realistic accounting of all items, which is extensively discussed in section 4.1 . 
For the flooding scenario, the initial quantities and therefore the construction phase are the same. 221 However, the maintenance cycles change due to the introduction of a flood. Utilizing the damage functions 222 introduced in section 2.2, the additional materials needed for flood related repairs are incorporated:

$$
I F_{i, f l o o d}=I Q_{i} \cdot\left(D_{i}(F D)+\frac{L_{H}}{L_{i}}\right)
$$

224

Once again, items with a lifetime of 50 years stood out as incorrect. Moreover, further complexity is introduced as IF calculation is impacted by how old the house is when the flood occurs. Both phenomena were accounted for by using the same methodology that allowed to correct Equation 1. Floods during eleven decades of the house's lifetime where considered, from decade 1 to 11 . This allowed to fully explore the second dimension of the flood scenarios, namely, the house age. The outputs are presented in section 3.1 and discussed in section 4.1.

\subsection{Assessing sensitivity}

A two-step sensitivity analysis is used to assess the model's robustness. The first step is a perturbation analysis where selected key parameters are varied in realistic ranges while the effect of the change on the results is expressed using sensitivity ratios, denoted $S R$ and calculated via Equation 3. For example, a ratio of 0.3 means that the relative change in results is $30 \%$ of the relative change in parameter. A linear influence of a parameter will therefore be reflected by a ratio of 1 .

$$
S R=\frac{\frac{\Delta \text { Results }}{\text { Initial result }}}{\frac{\Delta \text { Parameter }}{\text { Initial parameter }}}
$$
challenged. The first is the choice of insulation, which impact is assessed by investigating the impact of a change in insulation thickness. This was chosen because of the rapidly changing and non-uniform insulation policies across Europe. The second assumption checked is the structural frame's main component, namely, 
243 the cement facing bricks. The impact on the results of replacing them by either clay or shale bricks is 244 investigated.

\section{3. Results}

As mentioned in section 2.2.2, the results presented in this section were obtained using the $R e C i P e$ Midpoint (E) V1.13/Europe (Goedkoop et al., 2013) computed through the SimaPro software. This method does not have a normalization factor for water depletion, explaining the absence of this impact category when normalized results are presented. Moreover, when all impact categories could not be presented on a figure, climate change was used. It is believed that this impact category is communicative and is often representative of general behaviours. To mitigate the bias introduced by this truncated view, all the characterized results are included in the [supplementary material].

\subsection{Inventory}

The results of the method presented in section 2.3 are gathered in Table 4. Only two house ages are displayed in this table and throughout this study because they represent all the possibilities. Indeed, floods occurring during decades $1,5,6,10$ and 11 yield equal IFs and are represented by a flood during decade 5 . The same applies for floods occurring during decades 2, 3, 4, 7, 8 and 9, which are represented by a flood during decade 2. These equalities explain why only two decades are represented in Table 4. These equalities are a result of a shifting of timing of investment, which will be illustrated by Figure 3 . This means that nine water depths are considered for two house ages, effectively amounting to a total of eighteen flood scenarios. The results of Table 4 are further discussed in section 4.1. More detailed results, spread over the decades of 263 
267 calculated using Equation 1 and Equation 2. The corrected values for items with a lifetime of 50years are notified in italic.

\begin{tabular}{|c|c|c|c|c|c|c|}
\hline & $1 Q_{i}$ & Unit & $L_{i}(\mathrm{y})$ & $\begin{array}{l}\text { Baseline } \\
\left.\text { (IF } \text { I }_{i, \text { baseline }}\right)\end{array}$ & $\begin{array}{c}\text { Flood } \\
\text { during } \\
\text { decade } 5 \\
\left(\mathrm{IF}_{i, f l o o d}\right)\end{array}$ & $\begin{array}{c}\text { Flood } \\
\text { during } \\
\text { decade } 2 \\
\left(\mathrm{IF}_{i, f l o o d}\right)\end{array}$ \\
\hline Paint & 87.7 & $\mathrm{~kg}$ & 10 & 1053 & 1133 & 1133 \\
\hline Ventilation duct & 21.4 & $\mathrm{~m}$ & 20 & 129 & 140 & 140 \\
\hline Mechanical ventilation & 1 & $p$ & 20 & 6 & 6 & 6 \\
\hline Socket & 30 & $p$ & 20 & 180 & 185 & 185 \\
\hline Switch & 16 & $p$ & 20 & 96 & 99 & 99 \\
\hline MCB & 1 & $\mathrm{p}$ & 20 & 6 & 7 & 7 \\
\hline Water heater & 1 & $p$ & 30 & 4 & 5 & 5 \\
\hline Wall light & 6 & $p$ & 30 & 24 & 25 & 25 \\
\hline Suspended light & 9.0 & $p$ & 30 & 36 & 36 & 36 \\
\hline Window & 13 & $\mathrm{~m}^{2}$ & 30 & 52 & 53 & 53 \\
\hline Radiator & 16 & $p$ & 40 & 48 & 57 & 57 \\
\hline Kitchen cabinet & 4 & $p$ & 50 & 12 & 16 & 12 \\
\hline Living room furniture & 1 & $p$ & 50 & 3 & 4 & 3 \\
\hline Wardrobe & 2.0 & $p$ & 50 & 6 & 8 & 6 \\
\hline WC, ceramic & 2 & $p$ & 50 & 6 & 7 & 6 \\
\hline PVC pipe & 36.5 & $\mathrm{~m}$ & 50 & 110 & 117 & 110 \\
\hline Kitchen sink & 1.0 & $p$ & 50 & 3 & 4 & 3 \\
\hline Bathroom sink & 2.0 & $p$ & 50 & 6 & 7 & 6 \\
\hline Ceramic tile & 65.5 & $\mathrm{~m}^{2}$ & 60 & 131 & 197 & 197 \\
\hline Wooden flooring & 67.1 & $\mathrm{~m}^{2}$ & 60 & 135 & 202 & 202 \\
\hline Door, entrance & 1.0 & $p$ & 60 & 2 & 3 & 3 \\
\hline Door, inner & 8 & $p$ & 60 & 16 & 22 & 22 \\
\hline Baseboard, MDF & 60.3 & $\mathrm{~m}$ & 60 & 121 & 181 & 181 \\
\hline Baseboard, ceramic & 64.3 & $\mathrm{~m}$ & 60 & 129 & 193 & 193 \\
\hline Sheetrock & 369.4 & $\mathrm{~m}^{2}$ & 120 & 370 & 534 & 534 \\
\hline Stone wool, wall & 1115 & $\mathrm{~kg}$ & 120 & 1115 & 1589 & 1589 \\
\hline Stone wool, ceiling & 1400 & $\mathrm{~kg}$ & 120 & 1400 & 1400 & 1400 \\
\hline Cable & 172 & $\mathrm{~m}$ & 120 & 172 & 199 & 199 \\
\hline Roof tile & 6162.6 & $\mathrm{~kg}$ & 120 & 6163 & 6163 & 6163 \\
\hline Siding & 104.6 & $\mathrm{~m}^{2}$ & 120 & 105 & 108 & 108 \\
\hline Foundation & 132 & $\mathrm{~m}^{2}$ & 120 & 132 & 132 & 132 \\
\hline Slab & 132 & $\mathrm{~m}^{2}$ & 120 & 132 & 132 & 132 \\
\hline Structural frame & 132 & $\mathrm{~m}^{2}$ & 120 & 132 & 137 & 137 \\
\hline
\end{tabular}


271 Looking at the impacts occurring through time allows for investigation of the contribution of each stage 272 but also helps illustrate the way maintenance cycles shift when a flood occurs. Figure 2 shows relative climate 273 change results for the baseline scenario plotted against time. The largest impact, by far, is the initial 274 construction. This is due to the group of items lasting for the whole life of the house, namely, the structural 275 frame, foundation, slab, gypsum plasterboard and insulation. The initial construction amounts to $67 \%$ of the 276 house's impact on climate change, and $55 \%$ on average in all impact categories.

277 The other large impacts occur during decades 3, 6 and 9 which is mostly due to the replacement of the 278 items with lifetimes of 20,30 , and 60 years. One may also notice the significant impact occurring during decade 2795 and 10 that accounts for $5 \%$ of the total impact each. This highlights the fact that the model chooses to 280 replace items with a lifetime of 50 also during decade 10 , a choice that probably would not be made in a 281 realistic setting. If this group of items were not replaced, the total climate change impact of the baseline 282 scenario would go down by 3.9\%. Given that the used-up group of items would still have to be maintained by 283 replacement with items of shorter lifetimes, which would come with its own environmental impact, the 284 overestimation is believed to be negligible. 


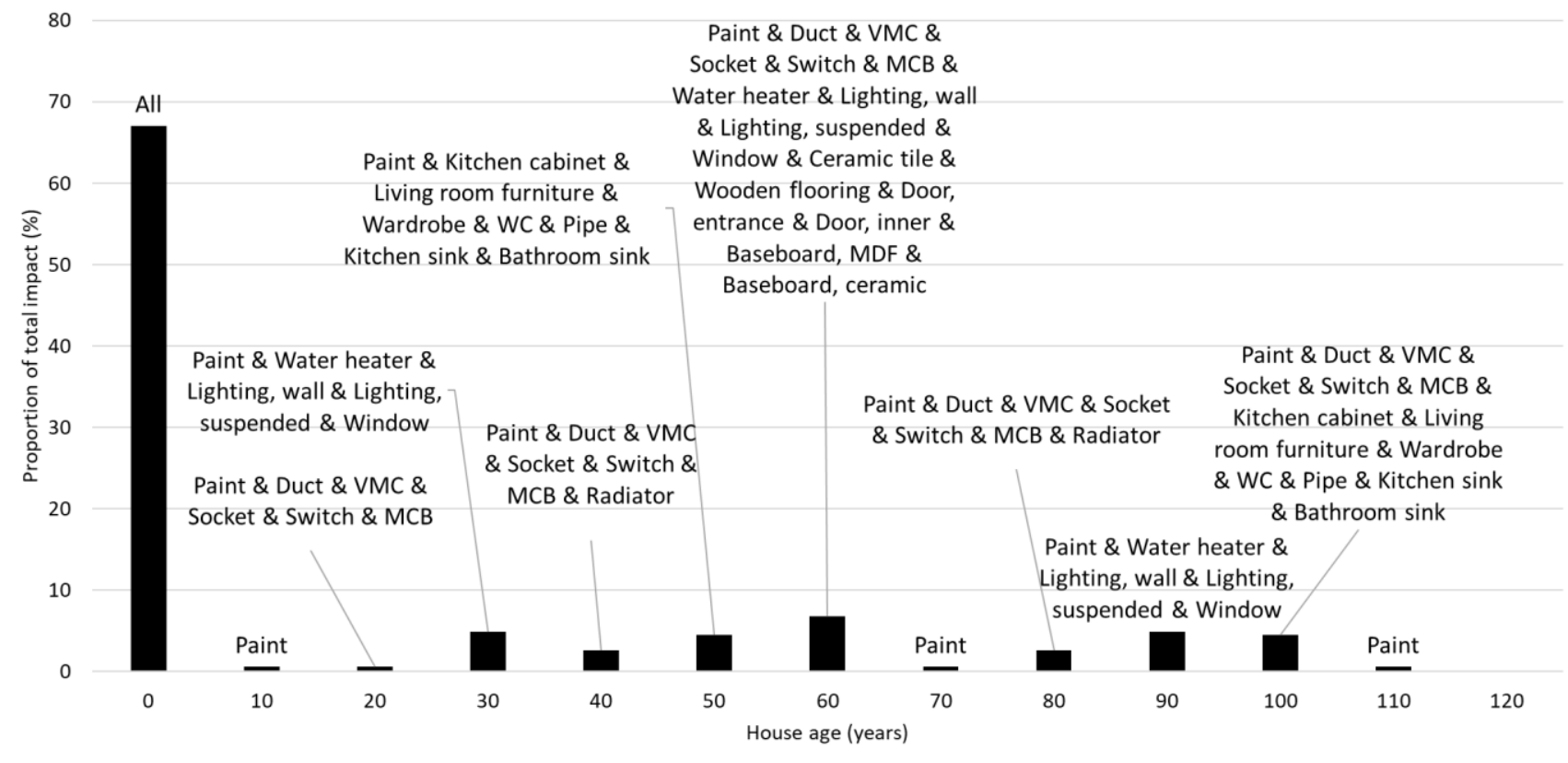

Figure 2 - Climate change results for the baseline scenario, expressed as a percentage of the total baseline impact, spread over the twelve decades of the house's life cycle. Each decade shows the list of items replaced.

Figure 3 shows the relative difference between the baseline and two floods scenarios, expressed against time and calculated from normalized climate change results. The two floods considered have water levels of $0.5 \mathrm{~m}$ and occur during decades 2 and 5 .

Before the flood occurs, there is no difference between the baseline and flood scenarios. The impact of flood related repairs is denoted by a red outline, which represents the direct component of the flood's impact. 293 This direct impact is equal for both flood scenarios, amounting to $9.6 \%$ relative additional impact. This was expected as the IFs for flood related repairs and calculated identically in both cases, using the first part of 295 Equation 2. After the flood, the maintenance cycles of several items are shifted through time because the natural disaster forces early replacements, which in turn moves impacts. This constitutes the indirect 297 component of the flood's impact. For a flood occurring during decade 5, these shifts cancel out, and the entirety 298 of the flood's direct impact is carried out in overall difference. On the contrary, a flood occurring during decade 2992 ends up having a lower overall impact because the direct impact of the flood is mitigated by its indirect component. This will be further discussed in section 4.1, on the level of IFs. 


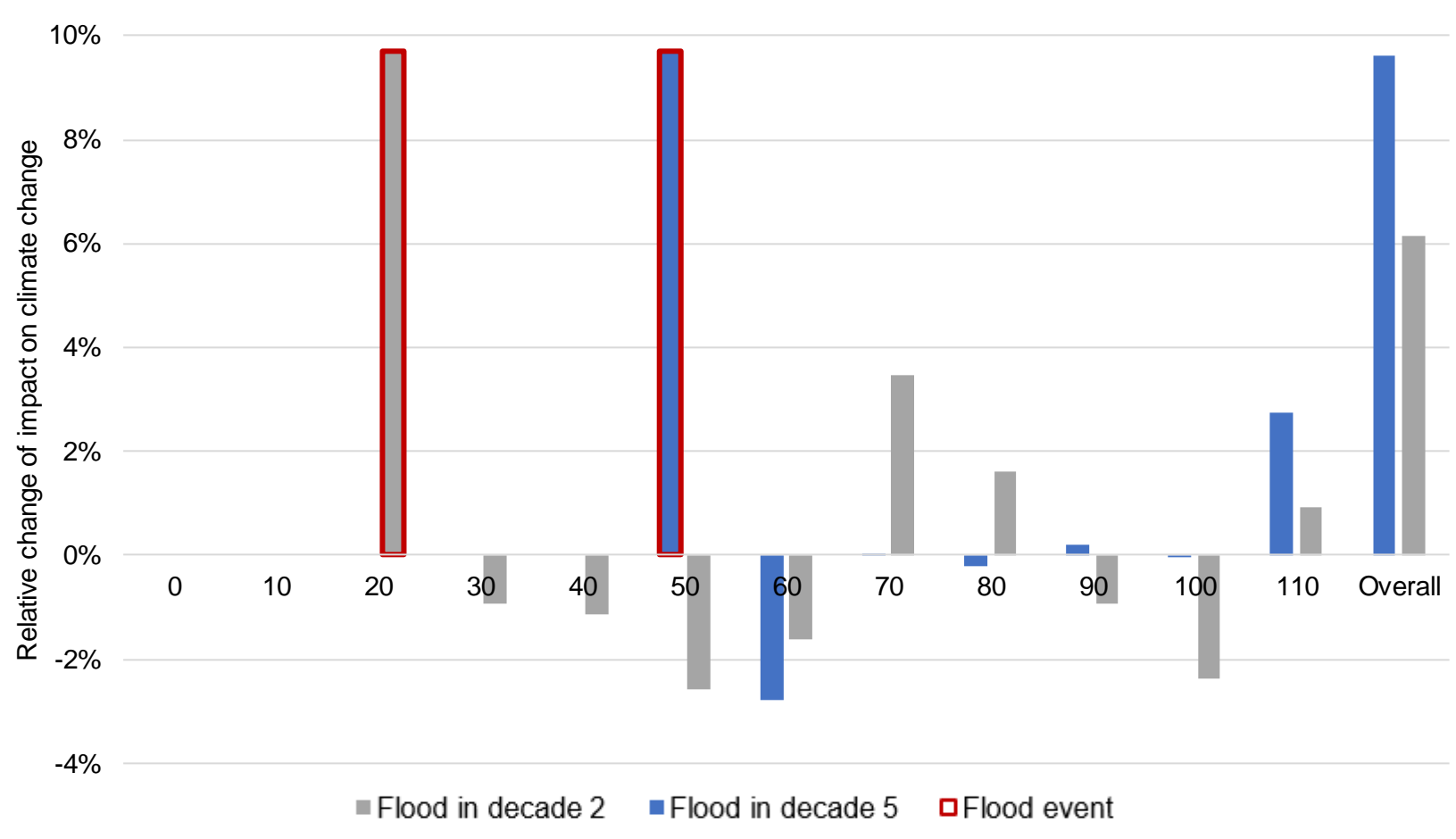

Figure 3 - Change introduced by floods of $0.5 \mathrm{~m}$ during decade 2 and 5 relative to the baseline scenario, visualized through time and calculated from climate change normalized results.

\subsection{Summed normalized results}

Figure 4 provides an overview of the results summed for all items and phases. The normalized impacts of the baseline scenario for all categories are expressed in Person Equivalent (PE) with data labels while the additional impact caused by two $0.5 \mathrm{~m}$ floods occurring during decades 2 and 5 is expressed relative to the baseline impact (\%). The first observation is that, disregarding the impact category considered, the scenario with a flood during decade 5 has the highest impact, followed by the flood during decade 2 . This is in line with the climate change impacts results of the precious section. On average across categories, floods during decades 2 and 5 add 7.7 and $11.8 \%$ to the baseline scenario, respectively.

Furthermore, large disparities between categories can be observed when looking at the absolute normalized impact of the baseline in the data labels of Figure 4. Impacts range from a few tenth of PE for ozone depletion to hundreds of PE for marine ecotoxicity. Moreover, considering that this single-family residence can provide housing for an average of 3.5 individuals during 120 years, it amounts to 420PE for housing. Moreover, when looking at climate change, only $2 \%$ of the house's inhabitants' equivalent impact is 

considered here, which is by far the most impactful (Rasmussen and Birgisdottir, 2015).

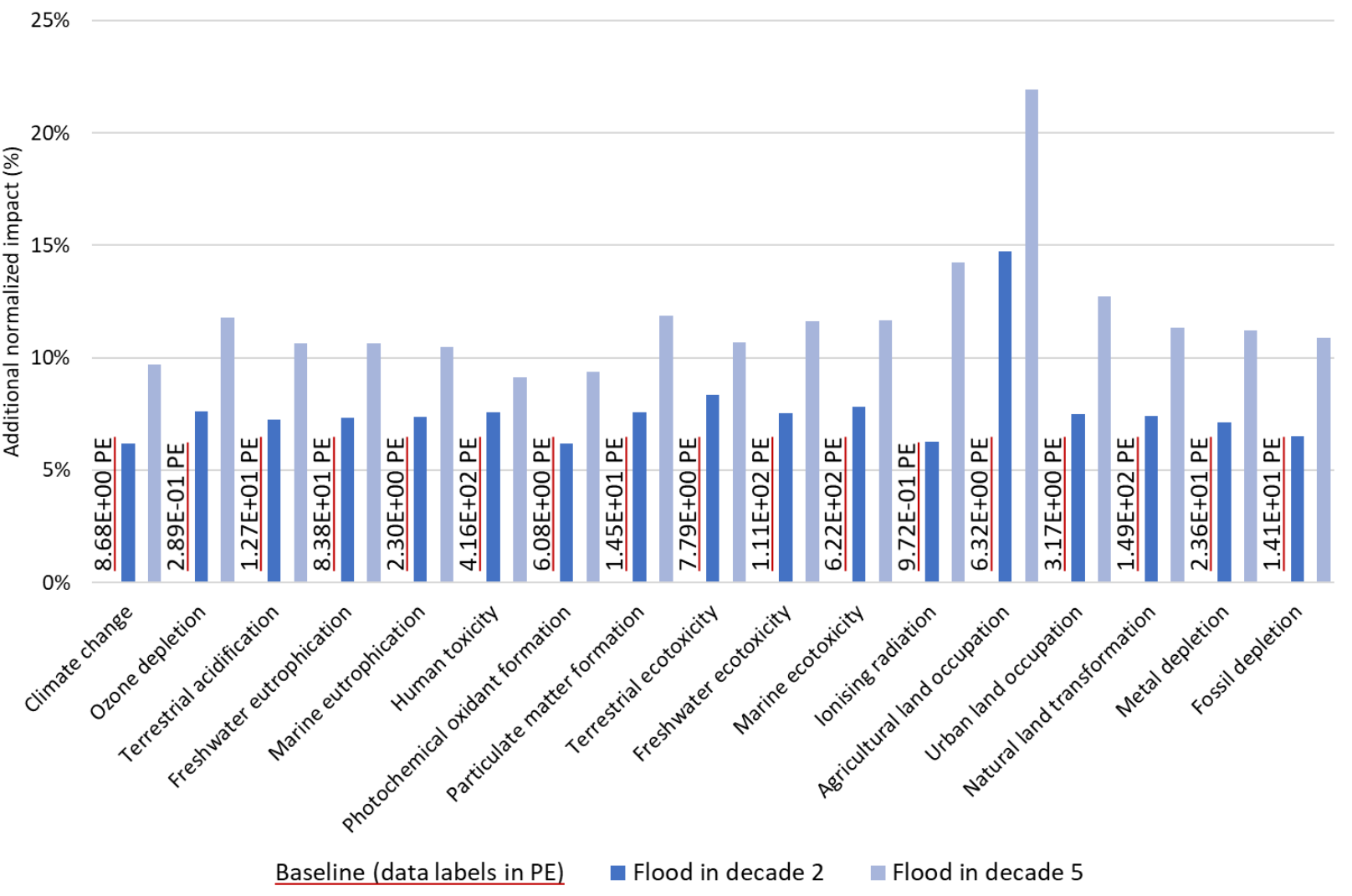

Figure 4 -Additional impact (\%) of two $0.5 \mathrm{~m}$ flood occurring during decades 2 and 5 , relative to the baseline normalized results in absolute value displayed in data labels (Personal equivalent, PE), summed for all items of the house, for all impact categories. Phases as described in Table 1 are included.

to a baseline house and from four standpoints:

\subsection{Impact of flood related repairs related to flood depth}

Figure 5 shows the additional damage resulting from a single flood plotted against the water level, relative

1) the additional environmental impact (\%) caused by a flood with worst possible timing (during decade 5), calculated from the results of this study, on average for all impact categories

2) the same additional environmental impact (\%) calculated identically, but for a flood with best possible timing (during decade 2)

3) the evolution of flood damage with depth (\%, right axis), as calculated by the USACE (USACE, 2006) in the North-American context, relative to the maximum flood damage. 
4) the evolution of flood damage with depth (\%, right axis), as calculated in the work commandeered by the Joint Research Centre (JRC) (Huizinga, 2007) in the European context, relative to the maximum flood damage.

Curves 1) and 2) represent the same notion that was introduced when comparing scenarios on Figure 4. Overall, the additional environmental impact resulting from a single flood ranges from $3.5 \%$ to $17.8 \%$ from floods of $0 \mathrm{~m}$ occurring during decade 2 to floods of $2.1 \mathrm{~m}$ during decade 5 , respectively. It is argued that realistic additional damage would fall in the area in between the two curves (denoted in blue on the figure), with the two curves representing the worse and best cases. Actual damage would depend on the precise age of the house when the flood occurs and hence on exactly how good or poor the flood timing was.

Comparing the area of realistic additional damage with curve 3) allows to conclude that the environmental impact of a flood is correlated to its economic impact, especially for low flood depths. The fact that the work of the USACE was used to model the environmental impacts in the first place is partly responsible for this result. However, if the environmental weight of the items had been distributed differently, this correlation would have been refuted. This is a major result as this correlation is often an assumption in literature and has not been verified explicitly before. The correlation can be verified for all impact categories individually, except for agricultural land occupation and ionising radiation as documented in the [supplementary material].

The flood damage assessment of this study is based on the work of USACE which is contextualized in the US, whereas this study intends to yield results representative for Europe. This calls for the comparison made in between curves 3) and 4). The damage function calculated by the USACE was compared to the work commandeered by the European JRC (Huizinga, 2007). It is a far-reaching attempt to catalogue traditional economic damage curves on the level of land uses, for water levels of 0 to $6 \mathrm{~m}$, and for the 27 countries that were in the EU in 2007. The data chosen for Figure 5 is their average findings for the residential buildings, across all the countries considered. It shows that the evolution of the two curves is similar enough to yield representative results in the range of water levels considered. 


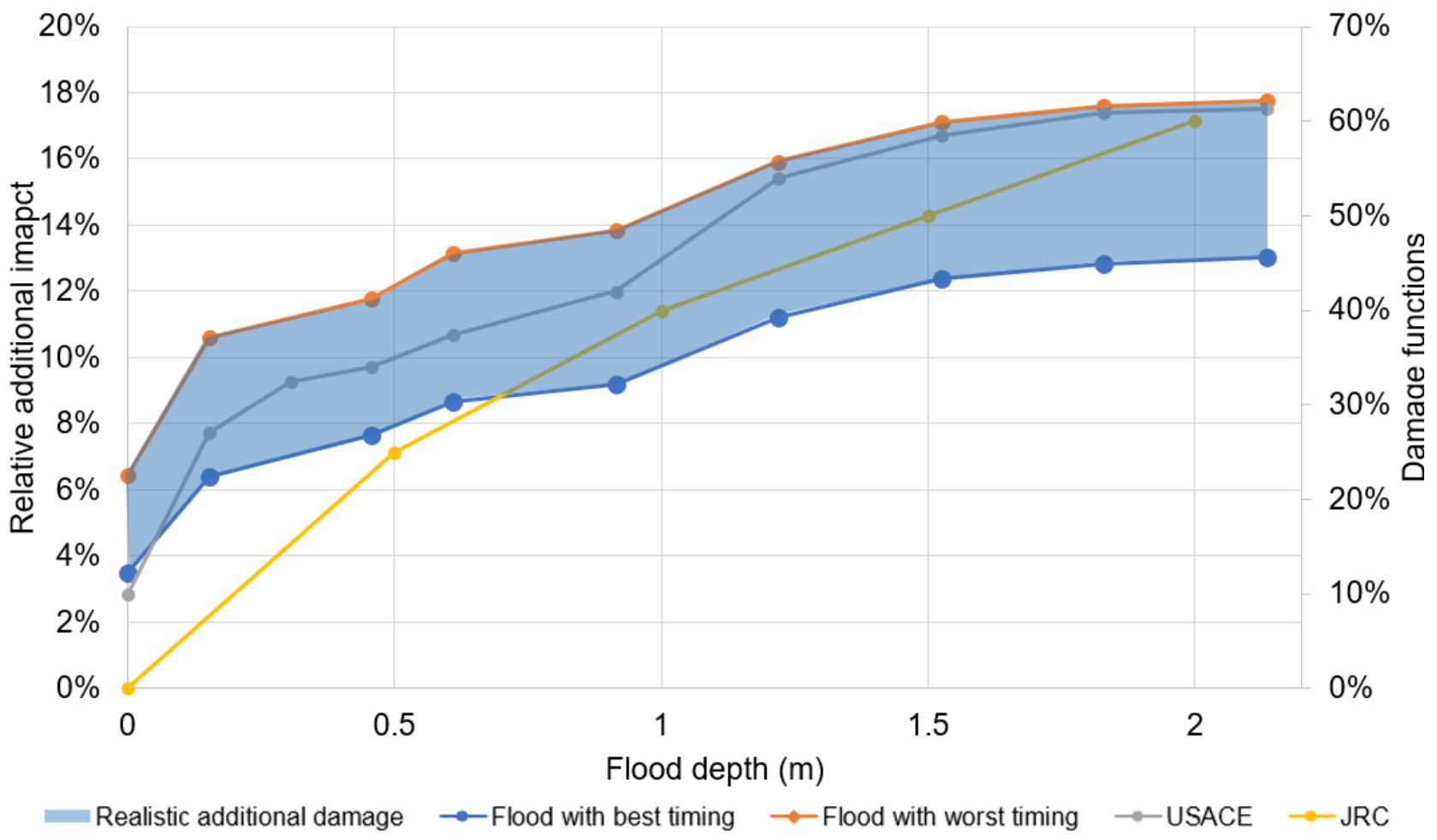

Figure 5 - Additional environmental impact caused by floods with best and worst timings relative to the baseline house (primary axis), as well as the economic damage functions from USACE and JRC for European and North-American contexts (secondary axis), plotted against flood depth (m).

\section{Discussion}

\subsection{Limitations}

It is argued that the way item flows are calculated, meaning how flood related repairs are integrated in the life cycle of the house, is a significant choice. Indeed, the method chosen determines whether the house age will have an impact on the results. By laying down IFs throughout the decades, amounts close to reality were obtained which account for the influence of the house age. The fact that decadal cycles of maintenance is a simplification that lead to a division of the results in a worst and a best scenario is argued to be an acceptable trade-off.

The method chosen therefore allows to account for the fact that maintenance cycles shift when a flood forces early replacement. To illustrate that, one may notice that three categories of items arise when looking at the IFs results (cf. Table 4 and [supplementary material]). 
First, for items with a lifetime of 20 years or lower, the introduction of a flood does not impact the IF. 374 Simply said, this group of items would have been replaced with or without flood. This result notably justifies 375 the exclusion of the content of the house (i.e. consumers electronics or cloths), as they have even shorter 376 lifetimes. A second group of items, with lifetimes that are higher or equal to 30 and also are a multiple of 120 377 years, see their IF go up with a flood, but are not impacted by the house age. Their maintenance cycle is 378 affected by the natural disaster but can shift freely through time disregarding of when it occurs (see 379 [supplementary material]). A final group of items, with a lifetime of 50years, also see their IF go up with the 380 introduction of a flood but in different amounts depending on the age of the house age.

381 Representing flood damage using solely the indicator of maximum flood depth is criticized by some 382 because it does not consider flood velocity and duration or failures occurring when structures are lifted 383 (Huizinga, 2007; Middelmann-Fernandes, 2010; USACE, 2006). In this study, the duration of the flood is 384 specified, and no flood depths higher than $2.1 \mathrm{~m}$ are considered specifically to avoid the uncertainty linked to 385 high velocity waters. Adding the fact that flood damage is assessed on the item level as opposed to land uses, 386 387 framework.

Other factors are limiting, albeit to a lesser extent. The eclectic nature of the sources used for the LCls of the 32 individual LCAs conducted on the items of the house leads to varying degrees of precision. For example, while packaging is included in most LCls, some include specific values while other just work with assumptions based on the overall weight of the product. This means that the overall representativeness of the LCA is difficult to discuss. The difficulty of comparing these results to other study in a direct way is another limiting factor. To the authors' knowledge, the closest approach in literature is the work of Matthews conducted in 2016 (Matthews et al., 2016). However, even in that case, they dealt with the issue statistically using a Monte-Carlo analysis that accounts for sea level rise, and they studied a comparison with a flood resilient house design in the North-American context. These differences set it too far apart from our method for any worthwhile direct comparison of results. Further work was however based on this model of a single-family residence which may make for easier comparisons (Hennequin et al., 2018).

\subsection{Sensitivity analysis}

\subsubsection{Perturbation analysis}


The methodology presented in section 2.4 is used to assess the robustness of the model. The influence

402

403

404

405

406

407

408

409

410

of 16 key parameters on the results was assessed by calculating their sensitivity ratios with Equation 3 , which were averaged for all impact categories and reported on Figure 6. These were calculated using characterized results of the scenario with a flood of $0.5 \mathrm{~m}$ occurring during decade 5 . Both the parameters range of variation and the complete collection of sensitivity ratios can be found in the [supplementary material].

The first observation is that no parameters is overpowering the results. The maximum ratio is 0.36 for the paint usage in the natural land occupation category, and the average of all the ratios is 0.063 with a standard deviation of 0.064 . The generally low ratios observed here are mostly due to the substantial number of items modelled, which all participate in the results in similar proportions. None of the parameters can be said to have an overwhelming influence on the results, which makes for a robust model.

Moreover, it can be observed that the results are most sensitive to the initial quantities of the structural frame, the lifetime and initial quantity of the furniture and windows as well as the paint usage. Finally, the results show that none of the impact categories are significantly more sensitive to the changes in parameters than another. Averaging the ratios per category yields ratios ranging from 0.046 for human toxicity to 0.076 for water depletion.

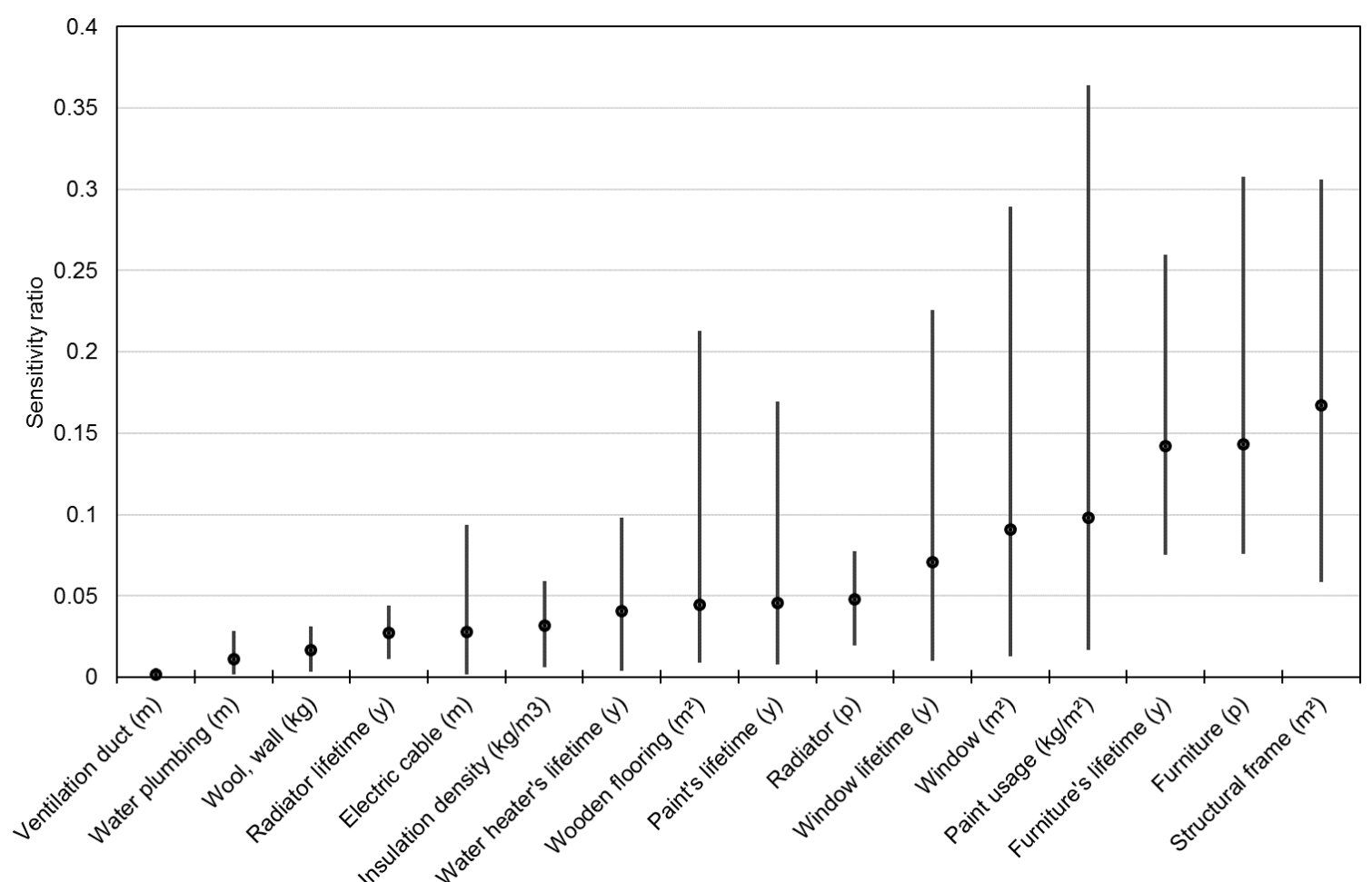



using Equation 3.

\subsubsection{Assumption check}

The result of the four assumption checks presented in section 2.4 are presented in Figure 7 . The influences 421 of the changes made to the model are compared to the scenario with a $0.5 \mathrm{~m}$ flood during decade 50 , taken as 422 a reference. Characterized impact on climate change have been chosen to build the figure for the sake of 423 clarity, However, whenever climate change is not representative of the behaviour of the rest of the categories, 424 it is discussed.

425 A $10 \mathrm{~cm}$ thicker insulation brings the reference flow of wall and ceiling insulation for reference scenario 426 from 2989 to $4483 \mathrm{~kg}$. Using thicker stone wool insulation logically makes the impact of the reference scenario 427 go up, by $2 \%$ in average across all impact categories. However, if the use phase of the house was included, 428 the savings on heating might counterbalance that negative effect, making for a worthy trade-off.

429 The brick reference flow for clay and shale was respectively adjusted to 25410 (Littlehampton, 2017) and $43024717 \mathrm{~kg}$ (SImetric, 2016). For both types of bricks, the impact of the reference scenario goes down, by $15 \%$ 431 and $17 \%$ for the clay and shale when looking at climate change and 8 and $5 \%$ in average across all impact 432 categories. The large effect of these changes is due to the fact that the structural frame is a major hotspot of 433 the baseline scenario and SimaPro results showed that the fibre cement bricks were responsible for most of 434 that impact. 


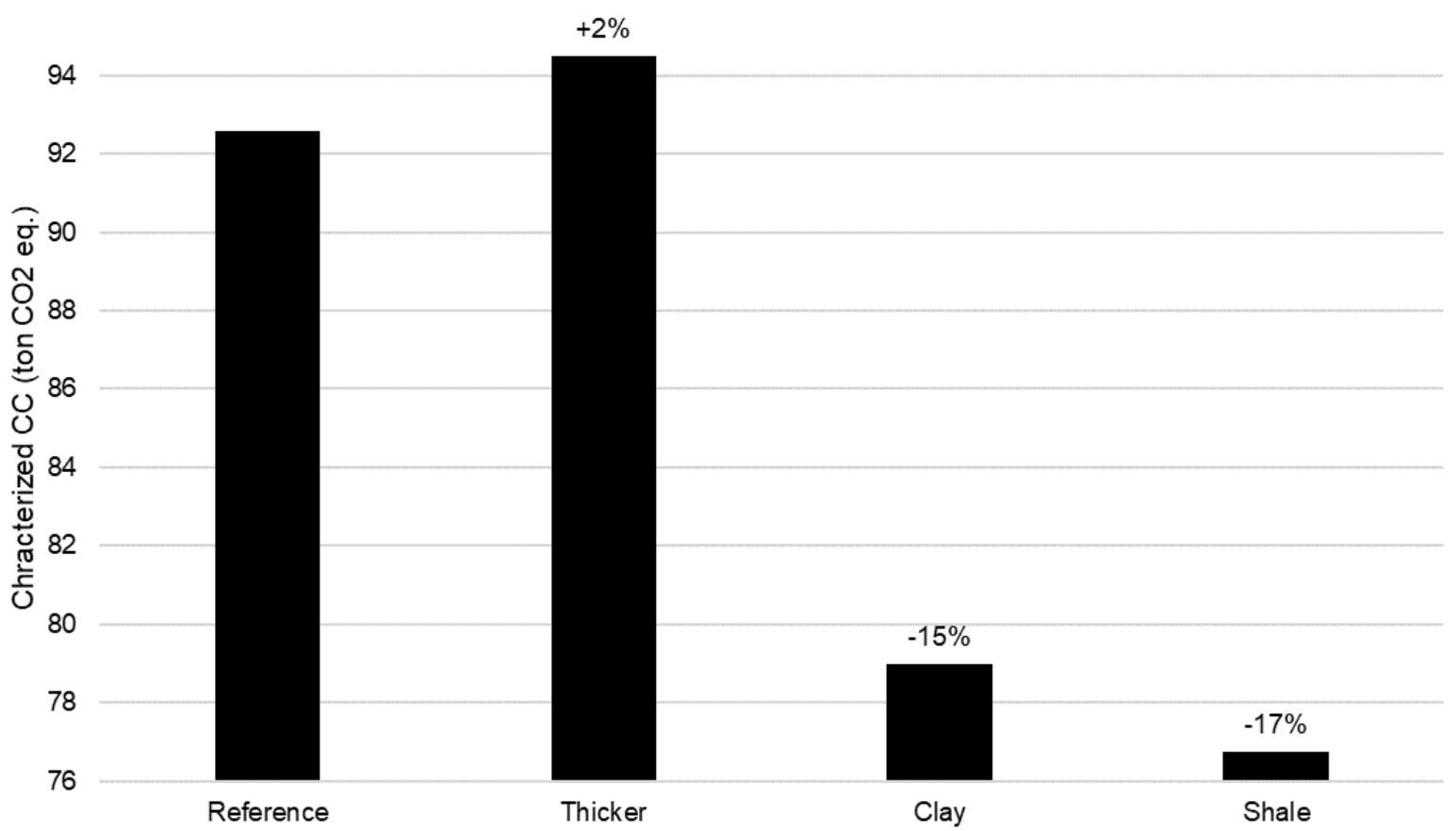

Figure 7 - Assumption check with results as characterized impact on climate change (ton CO2 eq.) and a flood of $0.5 \mathrm{~m}$

\section{Conclusion}

This study has presented a holistic method to assess the environmental impact of a house's flood related repairs. It was chosen to focus on the residential portion of the built environment as it is the part most heavily affected by flood. The method was exemplified by studying a European single-family residence built in the 2010's.

The main conclusions of the study can be summarized as:

- With or without flooding, the main impact of the life cycle of a house is its construction, when omitting the use phase. The initial construction amounts to $55 \%$ of total impact when no flooding is occurring and to $50 \%$ when the house is flooded once. This is because several impactful elements are built only once at the beginning, namely, the structural frame, the foundation, the slab, the insulation and the gypsum plasterboard.

- A correlation between the economic impact of a flooding event and its environmental impact is demonstrated. It is valid for most impact categories, expect for agricultural land occupation and ionizing radiation, and between water levels of 0 and $2.1 \mathrm{~m}$. 
- The main element of the single-family residence impacting the environment is the structural frame which makes up one fifth of the total impact. $80 \%$ of the frame's impact is due to its cement facing bricks. This could be mitigated using shale or clay bricks instead.

- The main elements of the flood related repairs impacting the environment are the wooden flooring, the water heater, and the furniture. Together, they account for half of the impact of the renovation needed after a flood.

- When a house is flooded with a water level of $0.5 \mathrm{~m}$, the additional environmental impact will range from 8 to $12 \%$. The extent of the increase depends on when the flood occurs. This range will evolve from 3.5$6.4 \%$ to $13-17.5 \%$ when the water level increases from 0 to $2.1 \mathrm{~m}$.

This study has the ambition to be part of the foundation for further studies dealing with the environmental impact of flooding. Larger questions can be answered using this method as groundwork, notably dealing with climate change adaptation and risk assessment. For example, by building upon this LCA study one could inform decision makers on strategic options of flood risk management.

\section{Acknowledgement}

Part of the work was carried out as part of the Innovation network Water in Urban Areas, supported financially by the Ministry for Higher Education and Science under contract 1363-00039B.

\section{References}

Aerts, J.C.J.H., Botzen, W.J., Clarke, K.C., Cutter, S.L., Hall, J.W., Merz, B., Michel-Kerjan, E., Mysiak, J., Surminski, S., Kunreuther, H., 2018. Integrating human behaviour dynamics into flood disaster risk assessment. Nat. Clim. Chang. https://doi.org/10.1038/s41558-018-0085-1

AFISB, 2014. Évier en grès émaillé [WWW Document]. URL http://www.baseinies.fr/iniesV4/UploadedFiles/INIES_CÉVI20140415_144207/Évier_en_grès_émaillé_1_3.pdf (accessed 2.23.17). 
Arnbjerg-Nielsen, K., Leonardsen, L., Madsen, H., 2015. Evaluating adaptation options for urban flooding based on new high-end emission scenario regional climate model simulations. Clim. Res. 64, 73-84. https://doi.org/10.3354/cr01299

ATD, 2016. Average Life Span of Homes, Appliances, and Mechanicals [WWW Document]. URL http://www.atdhomeinspection.com/advice/average-product-life/ (accessed 7.16.17).

Bel'M, 2012. Déclaration Environementale - Porte d'entrée bois reconstitué non vitrée [WWW Document]. URL http://www.base-inies.fr/inies/UploadedFiles/1400_fdes portes bel'm_gamme bois 58mm_modeles non vitres_20 12 2012.pdf (accessed 2.24.17).

FCBA, 2015. Déclaration environmentale - Bardage peint en bois [WWW Document]. URL http://www.baseinies.fr/inies/UploadedFiles/INIES_CBAR20150925_104219/DE_Bardages_peints_sept.2015.pdf (accessed 2.24.17).

FMHE, 2017. Câble basse tension, 2.5mm² (16/20A), 0.5/1kV [WWW Document]. URL http://www.baseinies.fr/inies/UploadedFiles/Documentation-Cable_basse_tension.pdf (accessed 7.19.18).

FMHE, 2016a. Données Génériques - Chauffe eau gaz 10kW [WWW Document]. URL http://www.baseinies.fr/inies/UploadedFiles/Documentation-Chauffe-eau_gaz_10kW.pdf (accessed 7.19.18).

FMHE, 2016b. Interupteurs/sectionneurs domestiques [WWW Document]. URL http://www.baseinies.fr/inies/UploadedFiles/Documentation-Interrupteurs-sectionneurs.pdf (accessed 7.19.18).

FMHE, 2016c. Luminaires intérieurs étanches [P=54W et diam.=70mm] [WWW Document]. URL http://www.base-inies.fr/inies/UploadedFiles/DocumentationLuminaires_interieurs_etanches_P_54W_et_diam._70mm.pdf (accessed 7.19.18).

FMHE, 2016d. Plafonniers, Suspensions intérieurs linéaires pour éclairage tertiaire ou industriel [P=74W] 
[WWW Document]. URL http://www.base-inies.fr/inies/UploadedFiles/DocumentationPlafonniers_Suspensions_interieurs_lineaires.pdf (accessed 7.19.18).

FMHE, 2014a. Données Génériques - Conduits flexibles DN125mm [WWW Document]. URL http://www.base-inies.fr/iniesV4/UploadedFiles/Documentation-Conduits_flexibles_DN125mm.pdf (accessed 7.19.18).

FMHE, 2014b. Parquet de bois stratifié, 10mm [WWW Document]. URL http://www.baseinies.fr/inies/UploadedFiles/2093_evea pour sipev - fdes peintures mates en pa - 080611.pdf (accessed 7.19.18).

FMHE, 2014c. Données Génériques - Plinthe en bois reconstitué [WWW Document]. URL http://www.baseinies.fr/iniesV4/UploadedFiles/DocumentationPlinthe_en_bois_reconstitue_MDF_haut._7cm_et_ep.1cm.pdf (accessed 7.19.18).

FMHE, 2014d. Données Génériques - Plinthe en céramique [WWW Document]. URL http://www.baseinies.fr/iniesV4/UploadedFiles/Documentation-Plinthe_en_ceramique_haut._7cm_et_ep.1.4cm.pdf (accessed 7.19.18).

GIRPI, 2015. Canalisation eau potable PVC [WWW Document]. URL http://www.baseinies.fr/inies/UploadedFiles/INIES_ISYS20160314_165940/GIRPI_EPD_SYSTEM_O_format_FR_EN_158 04_CN.pdf (accessed 7.19.18).

Goedkoop, M., Heijungs, R., De Schryver, A., Struijs, J., van Zelm, R., 2013. ReCiPe 2008, A life cycle impact assessment method which comprises harmonised category indicators at the midpoint and the endpoint level.

Goldstein, B., Rasmussen, F.N., Goldstein, B., Rasmussen, F.N., 2018. LCA of Buildings and the Built Environment, in: Life Cycle Assessment. https://doi.org/10.1007/978-3-319-56475-3_28 
González-García, S., Gasol, C.M., Lozano, R.G., Moreira, M.T., Gabarrell, X., Rieradevall i Pons, J., Feijoo, G., 2011. Assessing the global warming potential of wooden products from the furniture sector to improve their ecodesign, Science of the Total Environment. https://doi.org/10.1016/j.scitotenv.2011.09.059

Groupe Atlantic, 2015. Profil Environnemental Produit Caisson de ventilation individuel simple flux VMC simple flux hygro [WWW Document]. URL http://www.baseinies.fr/iniesV4/UploadedFiles/PEPUploads/SCGA-00020-V01.01-FR_pdfpep_01.pdf (accessed 7.19.18).

Guha-Sapir, D., 2016. 2016 preliminary data1: Human impact of natural disasters.

Hennequin, T., Sørup, H.J.D.H.J.D., Dong, Y., Arnbjerg-Nielsen, K., 2018. A framework for performing comparative LCA between repairing flooded houses and construction of dikes in non-stationary climate with changing risk of flooding. Sci. Total Environ. 642, 473-484. https://doi.org/10.1016/j.scitotenv.2018.05.404

Hirabayashi, Y., Mahendran, R., Koirala, S., Konoshima, L., Yamazaki, D., Watanabe, S., Kim, H., Kanae, S., 2013. Global flood risk under climate change. Nat. Clim. Chang. 3, 816-821. https://doi.org/10.1038/nclimate1911

Huizinga, H., 2007. Flood damage functions for EU member states.

Ideal standard France, 2016. Pack WC (cuvette et réservoir) en porcelaine [WWW Document]. URL http://www.base-inies.fr/inies/Consultation.aspx (accessed 2.23.17).

Ideal standard France, 2015. Lavabo porcelaine [WWW Document]. URL http://www.baseinies.fr/inies/Consultation.aspx (accessed 2.23.17).

INIES, 2017. Inventaires de cycle de vie [WWW Document]. URL http://www.inies.fr/inventaires-de-cyclede-vie/ (accessed 3.10.17). 
Iritani, D.R., Silva, D.A.L., Saavedra, Y.M.B., Grael, P.F.F., Ometto, A.R., 2015. Sustainable strategies analysis through Life Cycle Assessment: A case study in a furniture industry, Journal of Cleaner Production. https://doi.org/10.1016/j.jclepro.2014.05.029

ISO, 2006a. EN ISO 14040:2006 - Environmental management - Life cycle assessment - Principles and framework. https://doi.org/10.1136/bmj.332.7550.1107

ISO, 2006b. EN ISO 14044:2006 -Environmental management - Life cycle assessment - Requirements and guidelines. https://doi.org/10.1007/s11367-011-0297-3

Khasreen, M.M., Banfill, P.F.G., Menzies, G.F., 2009. Life-cycle assessment and the environmental impact of buildings: A review. Sustainability 1, 674-701. https://doi.org/10.3390/su1030674

Lasvaux, S., Lebert, A., Achim, F., Grannec, F., Hoxha, E., Nibel, S., Schiopu, N., Chevalier, J., 2017. Towards guidance values for the environmental performance of buildings: application to the statistical analysis of 40 low-energy single family houses' LCA in France. Int. J. Life Cycle Assess. 22, 657-674. https://doi.org/10.1007/s11367-016-1253-z

Legrand, 2016. Prise 2 P+T - 16 A - Bornes auto - Pur [WWW Document]. URL http://www.baseinies.fr/inies/UploadedFiles/PEPUploads/LGRP-00036-V01.01-FR_pdfpep.pdf (accessed 7.19.18).

Littlehampton, 2017. Brick information - height, weigh, dimensions [WWW Document]. URL http://littlehamptonbrick.com.au/clay-bricks/brick-specifications/ (accessed 7.29.17).

Matthews, E., Friedland, C.J., Orooji, F., 2016. Integrated environmental sustainability and resilience assessment model for coastal flood hazards. J. Build. Eng. 8, 141-151. https://doi.org/10.1016/j.jobe.2016.08.002

Middelmann-Fernandes, M.H., 2010. Flood damage estimation beyond stage-damage functions: An 
Morita, M., 2008. Flood risk analysis for determining optimal flood protection levels in urban river management. J. Flood Risk Manag. 1, 142-149. https://doi.org/10.1111/j.1753-318X.2008.00016.x

Munich Re, 2017. Natural catastrophe losses at their highest for four years [WWW Document]. Munich RE. URL https://www.munichre.com/en/media-relations/publications/press-releases/2017/2017-01-04-pressrelease/index.html (accessed 1.31.19).

Petit-Boix, A., Arahuetes, A., Josa, A., Rieradevall, J., Gabarrell, X., 2016. Are we preventing flood damage eco-efficiently? An integrated method applied to post-disaster emergency actions. Sci. Total Environ. https://doi.org/10.1016/j.scitotenv.2016.12.034

Petit-Boix, A., Sevigné-Itoiz, E., Rojas-Gutierrez, L.A., Barbassa, A.P., Josa, A., Rieradevall, J., Gabarrell, X., 2017. Floods and consequential life cycle assessment: Integrating flood damage into the environmental assessment of stormwater Best Management Practices. J. Clean. Prod. 162, 601-608. https://doi.org/10.1016/j.jclepro.2017.06.047

Peuportier, B.L.P., 2001. Life cycle assessment applied to the comparative evaluation of single family houses in the French context. Energy Build. 33, 443-450. https://doi.org/10.1016/S0378-7788(00)00101-8

Pré Consultants BV, 2018. SimaPro [WWW Document]. URL https://simapro.com/ (accessed 3.29.18).

Rasmussen, F.N., Birgisdottir, H., 2015. Bygningens Livscyklus: Identifikation af væsentlige bygningsdele, materialegrupper og faser i en miljømæssig vurdering. København SBI Forl. 2015:09.

Roux, C., Schalbart, P., Peuportier, B., 2016. Analyse de cycle de vie conséquentielle appliquée à l'étude d'une maison individuelle. Conférence IBPSA Fr. 1-8.

Sarkisian, M.P., 2014. Design of environmentally responsible structures in regions of high seismic risk. 
Schneider Electric, 2014. Product environmental profile- Harmony 9001KQ [WWW Document]. URL http://www.base-inies.fr/inies/UploadedFiles/PEPUploads/HAGE-2014-030-V1-EN_pdfpep.pdf (accessed 2.23.17).

SImetric, 2016. Density of materials [WWW Document]. URL https://www.simetric.co.uk/si_materials.htm (accessed 7.29.17).

Sudret, B., Mai, C., Konakli, K., 2014. Assessment of the lognormality assumption of seismic fragility curves using non-parametric representations 1451-1467. https://doi.org/10.1002/eqe

Thermor, 2015. Radiateur electrique mural 1kW [WWW Document]. URL http://www.baseinies.fr/inies/UploadedFiles/PEPUploads/SCGA-00007-V01.01-FR_pdfpep_02.pdf (accessed 7.19.18).

UN, 2014. World Urbanization Prospects, UNDESA. https://doi.org/10.4054/DemRes.2005.12.9

UNEP, 2012. Building Design and Construction : Forging Resource Efficiency and Sustainable Development, United Nations Environment Programme.

USACE, 2006. Depth-Damage Relationships for Structures, Contents, and Vehicles and Content-to-Structure Value Ratios (CSVR) in Support of the Lower Atchafalaya Reevaluation and Morganza to the Gulf. refurbishment: A literature review. Energy Build. 135, 286-301. 